\title{
URBAN DEVELOPMENT AND PROPERTY MANAGEMENT IN THE CONTEXT OF SOCIETAL TRANSFORMATIONS: STRATEGIC DECISION-MAKING
}

\author{
Borisas MELNIKAS \\ Department of International Economy and Management, Faculty of Business Management, Vilnius Gediminas \\ Technical University, Sauletekio al.11, LT-10223 Vilnius-40, Lithuania \\ E-mail: melnikas@vv.vtu.lt
}

Received 3 April 2005; accepted 10 July 2005

\begin{abstract}
The urgent problems of urban development and strategic property management in the context of economic, social, political transformations in the society are analyzed. The possibilities of multicriteria strategic decision-making are described. The following objects are analyzed: urban development under the conditions of transformations as a major research object in the area of strategic property management; cities and their development as an environment of property creation and accumulation; transformation processes as general context of the urban development and of the creation and accumulation of property; the major trends of the transformation processes in Central and Eastern Europe, the main criteria and indicators of them; the evaluation criteria used in the area of urban development and property strategic management in the conditions of transformation processes; multicriteria decision-making in the area of urban development and property strategic management.
\end{abstract}

KEYWORDS: Transformation; Central and Eastern Europe; Urban development; Property creation and accumulation; Strategic decision-making

\section{INTRODUCTION}

Social and economic development at present is characterized by many various factors of which the following are most important:

- urban development reflecting new trends in the formation of urbanization patterns and lifestyles;

- new processes in the creation and accumulation of property reflecting the values and interests of the society.

Both urban development and property creation and accumulation reflect the priorities given by the society to political, social, economic and technological development. This means that these processes may be evaluated from two perspectives:

- $\quad$ as a result and expression of changes taking place in society,
- $\quad$ as a number of factors influencing social development.

The treatment of the above processes in the context of the general processes of social development is particularly important for Central and Eastern Europe where fundamental changes had been made in the last two decades and are still taking place in all spheres of social life. Therefore, these societies are still referred to as transition societies.

Urbanization and property creation and accumulation have become an important object of strategic management in the time of transition, implying that this process requires the development of the appropriate methodology and adequate research.

The need for a complex approach to strategic problems associated with urban development and property creation and accumulation 
under the conditions of societal transformations allows us to state the research problem as follows: a modern theory of societal transformations and their management lacks solutions about complex strategic management of urban development and creation and accumulation of property. In fact, such processes as societal transformation, urban development, property creation and accumulation have not been considered within a unified system of management. Moreover, a modern theory of societal transformations lacks tools based on formal approaches which could be used in strategic management of urban development and property creation and accumulation.

An efficient way of solving the above problem is based on two ideas:

- first, the processes of societal transformation, urban development and property creation and accumulation should be approached as an object for complex strategic management: the integration of these processes into a single system allows for considering the theories of strategic management of societal transformations, urban development and the creation and accumulation of property from the perspectives other than the traditional views would allow us to do;

- second, to analyze the strategic management of urban development and the creation and accumulation of property under the conditions of societal transformations, multiple criteria evaluation and optimization methods may be applied. Wide areas of application of these methods demonstrated by Zavadskas and his colleagues show that they can be successfully applied to the analysis of the strategic management of urban development and property creation and accumulation in the period of societal transformations (Zavadskas and Kaklauskas, 1999; Zavadskas et al., 1999; Zavadskas et al., 2001a, Zavadskas et al., 2001b, Zavadskas et al., 2001c; Zavadskas et al., 2002; Zavadskas and Kaklauskas, 2003; Zavadskas et al., 2003a, Zavadskas et al., 2003b, Zavadskas et al., 2003c; Zavadskas and Antuchevičienè, 2004, Zavadskas et al., 2004a, Zavadskas et al., 2004b; Zavadskas and Kaklauskas, 2005).

The above considerations allow us to define the goal of the present work as a comprehensive analysis of urban development and the creation and accumulation of property as a complex object of strategic management, and a feasibility study of the application of multicriteria evaluation and optimization methods to strategic decision-making in the considered areas.

To achieve the specified goal, the following problems are solved in the investigation:

- the significance of the processes of urban development and the creation and accumulation of property in the transition period is shown,

- urban development and the creation and accumulation of property are described in terms of the transformation of the society,

- urban development and the creation and accumulation of property in the transition period are considered to be a complex object of strategic management,

- various interested parties and their objectives influencing the process of urban development are identified, and the ways of generating a set of criteria characterizing urban development under transition are outlined,

- the transformations which have been taking place in the states of Central and Eastern Europe in the transition period and which make the background of urban development and the creation and accumulation of property are described.

The main concepts relating to the ways of solving the above problems are discussed further in more detail. 


\section{URBAN DEVELOPMENT UNDER THE CONDITIONS OF SOCIETAL TRANSFORMATIONS AS A MAJOR RESEARCH OBJECT IN THE AREA OF STRATEGIC PROPERTY MANAGEMENT}

\subsection{Cities and their development as an environment of property creation and accumulation}

Urbanization is a key factor determining the advance of civilization at all stages of its development. Urban architecture, layout, development and quality standard of urban life are the main criteria characterizing political, social, economic and technological development of any state.

A concept of cities and their development has been analyzed in many theoretical studies from various perspectives, including historical, cultural, social, economic, architectural and other aspects. This concept serves as a basis for carrying out research in various areas related to urbanization (Zavadskas and Kaklauskas, 1999; Zavadskas et al., 1999; Zavadskas et al., 2001a, Zavadskas et al., 2001b, Zavadskas et al., 2001c; Zavadskas et al., 2002; Zavadskas and Kaklauskas, 2003; Zavadskas et al., 2003a, Zavadskas et al., 2003b, Zavadskas et al., 2003c; Zavadskas and Antuchevičienè, 2004, Zavadskas et al., 2004a, Zavadskas et al., 2004b; Zavadskas and Kaklauskas, 2005; Weiss, 2003, 2004; Leung and Hui, 2005; Hui and Tse, 2002; Burinskienè and Rudzkienè, 2004; Then, 2005).

One of the most promising approaches to urban development management is associated with the application of information technologies and 'e-city' creation.

A new and promising approach to urban development is connected with its analysis as the environment for property creation. There are several reasons for theoretical and practical development of this approach:

- an important criterion describing the economic and social development of any city is the property including real estate which was created and accumulated in it (the amount and quality of the property allows us to determine the economic potential of the city),

- the created and accumulated property, or the property which will be created in future, may be considered to be $a$ significant factor determining further development of the city (the property of the city and its structure are very important for attracting investments and purposeful implementation of the priority issues for economic, cultural, social and technological development, as well as for increasing employment and standard of living of the population).

These considerations allow us to characterize the relationship between urban development and the creation and accumulation of property in two ways:

- on the one hand, the creation and accumulation of property is a significant factor of urban development,

- on the other hand, the level of urban development and historical, cultural, economic, social, architectural and other aspects are very important factors determining the possibilities of property accumulation in various forms.

The city is the environment influencing the value of the created (or being created) property. It is well-known that the same property may have different values, depending on social, economical, cultural conditions and legal and political regulation (for this reason, the influence of the city as a complex environment on the property value is evident and extremely important).

From philosophical perspective it may be stated that the city as a whole is the property of the community. In this sense, property may be perceived as:

- the whole city, taking into account its historical, architectural, economical, social, cultural, political and other aspects,

- the whole property accumulated in the 
city, taking into account that the whole property accumulated in the city may be viewed as a very important characteristic of the city as the property.

The city as the environment influencing the processes of property creation and accumulation should be approached as a system: the need for using a systems approach to this environment is determined by a multidimensional relationship between social, economic, political and technological aspects of development. A highly promising method of evaluating this multidimensional relationship seems to be the application of multicriteria analysis and optimization (Low and Sloan, 2000; Ginevičius and Podvezko, 2005; Zavadskas and Kaklauskas, 1999; Zavadskas et al., 1999; Zavadskas et al., 2001a, Zavadskas et al., 2001b, Zavadskas et al., 2001c; Zavadskas et al., 2002; Zavadskas and Kaklauskas, 2003; Zavadskas et al., 2003a, Zavadskas et al., 2003b, Zavadskas et al., 2003c; Zavadskas and Antuchevičiene, 2004, Zavadskas et al., 2004a, Zavadskas et al., 2004b; Zavadskas and Kaklauskas, 2005).

Thus, theoretical and empirical studies of urban development may be considered effective if they approach the city and its development as the environment influencing the creation and accumulation of property.

\subsection{Cities and their development as the environment of property creation and accumulation under the conditions of globalization and societal transformations}

By considering cities and their development as the environment influencing the processes of the creation and accumulation of property, the following factors should be taken into account:

- globalization and social, economic, cultural and technological internationalization

- directly affecting urban development of any region and state,
- $\quad$ abrupt changes of values, life conditions and lifestyles perceived as political, social, economic and technological transformations (Altvater and Mahnkopf, 1996; Chortareas and Pelagidis, 2004; Boldrin and Canova, 2001; Cohendet and Stojak, 2005; Currie, 2000; Ein-Dor, Myers and Raman, 2004; Farnsworth, 2005; Goeransson and Soederberg, 2005; Grace and Butler, 2005; Hunt, 2000; Olsen and Osmundsen, 2003; Parker, 1998; Perraton, 2001).

The influence of globalization, internationalization and societal transformations on urban development and the creation and accumulation of property is different, including:

- stronger orientation to international quality standards and unification of the conditions of economic, legal and technological development,

- urban development is stronger affected by various cultural factors when the specific historical, cultural and architectural features of various cities and towns are 'overshadowed' by general internationally accepted models,

- international competition is getting stronger, growing in the areas of urban development and the creation and accumulation of property; under the conditions of free international market formation, the 'convergence' of economic conditions for business development and costs can be observed. This, in turn, increases the requirements to quality standards, effectiveness and innovations (i.e. international companies play an active part in developing any city, thereby increasing the competition),

- the increasing scientific and technological development also requires quick responses to new challenges and adapting to ever changing conditions in the areas of urban development and the creation and accumulation of property. During the last two decades the influence 
of globalization, internationalization and societal transformations on urban development and the creation and accumulation of property was particularly strong in the countries of Central and Eastern Europe. Dramatical changes in political, social and economic development were taking place in these states (Hayo and Seifert, 2003; Hofbauer, 2003; Lavingne, 1995; Melnikas, 1997a, 1997b; Melnikas, 1998a, 1998b, 1998c; Melnikas, 1999a, 1999b; Melnikas, 2000; Melnikas, 2002; Melnikas and Reichelt, 2004; Brunner, 2000; Bateman, 1997).

The same applies to the changes in real estate markets of the countries of Central and Eastern Europe (Melnikas, 1997a, 1997b; Melnikas, 1998a, 1998b, 1998c; Melnikas, 1999a, 1999b; Melnikas, 2000).

It may be stated that the countries of Central and Eastern Europe have acquired valuable experience in responding to radical changes as well as to challenges of globalization, internationalization and societal transformations.

This experience may be successfully used in future development, particularly, in strategic management in the areas of urban development and the creation and accumulation of property. This experience should be analyzed, generalized and used for the following reasons:

- the changes which took place in Central and Eastern Europe are of long-term nature,

- the changes which took place in Central and Eastern Europe strongly affect the development of Europe as a whole and the European Union in particular,

- the changes which took place in Central and Eastern Europe contributed to the formation of new priorities in lifestyles which may serve as a basis for generating a set of criteria and basic principles of decision-making in the area of urban development.

To improve the strategic management of the creation and accumulation of property, taking into account the processes of globalization, internationalization and societal transforma- tions, the emphasis should be placed on research in the following areas:

- identifying the major laws governing social, especially regional, transformations (this is of vital importance for Central and Eastern Europe because the period of transformations was too short and the process was too intense leading to the formation of the private capital and private sector which will play a major role in further creation and accumulation of property),

- identifying the main features of urban development under transition, paying attention both to general and specific features characteristic of some particular cities (this is also of special importance for Central and Eastern Europe because the conditions of transformations have always been important for urban development there).

Research carried out in the above areas could allow us to describe the environment of the creation and accumulation of property and strategic decision-making in property management.

\section{SOCIETAL TRANSFORMATIONS AS GENERAL ENVIRONMENT OF URBAN DEVELOPMENT AND THE CREATION AND ACCUMULATION OF PROPERTY}

\subsection{A concept and specific features of societal transformations in Central and Eastern Europe}

Transformations may be described in various terms, including their treatment as a general, political, social, economic and technological environment of urban development and the creation and accumulation of property.

Transformations are particularly important for the states of Central and Eastern Europe. While assessing opportunities and perspectives for further economic and social growth in the countries of Central and Eastern Europe, it is essential to consider a number of factors im- 
pelled by political, economic and social transformations, which took place in these countries over the last 15 years and are still on. Taking into account that transitions indicate a major trend of political, social and economic development of these countries, the states of Eastern and Central Europe are referred to as transition countries.

Political, economic and social development in the transition countries is characterized by some features common to all of these countries as well as by specific features characteristic only of some transition states (Melnikas, 2002). The ability to determine both general and specific features of transformations allows us to define the situation in a particular country, the priorities of its development as well as identifying and solving most urgent problems.

In determining general features representing major trends of political, social and economic development in a transition period, the following most important issues should be emphasized:

1. Constant orientation toward the new quality life, implying that in the period of transition the efforts are made to realize the norms, standards, ideals, and stereotypes of new quality life. The changes associated with the quality of life take place in the period of transition, which are aimed at changing life for the better. Thus, a new society based on such values as democracy, humanism and openness as well as declaring the priority of human rights, freedom and well - being has been formed in the states of Eastern and Central Europe in the time of transition.

2. A complex character of transitions, meaning that major changes are complex, embracing major areas of political, social and economic life as well as the development of modern technologies, environment protection, laws and other areas of social importance. A complex character of transitions may be considered one of the major features characteristic of the development of Eastern and Central European countries. In recent $10-15$ years the qualitative changes have taken place in the political, social and economic structures of the society, while a new scale of values, life styles and priorities has been introduced and a new social order combining the elements of Western democracy and some Eastern Europe's traditions has been established.

3. Moreover, the complexity of transitions in these countries manifests itself in versatile effects on various sides of life, which may be controversially assessed, because the results of the changes are not definitely outlined. The uneven character of transitions, implying that social changes often take place as a leap forward from one quality to another, These leaps are also characterized by profound and sudden changes. It is important to note that in the period of transition the society may experience shocks, when the traditional values and priorities are suddenly rejected, being replaced with some new values, of which the people have only superficial knowledge not being ready to adopt them. In the transition period, the formation of some political, social, economic, cultural and ideological vacuum is usually observed in the countries of Eastern and Central Europe due to a sudden character of changes often accompanied by instability.

4. Simultaneous and controversial character of transitions, meaning that different transitions may and do take place simultaneously, being, however, conflicting and imbalanced. As a result, the situation arises when one kind of transition is contrary to the others, which in turn may cause problems and even stresses in the society. The experience of the states of Eastern and Central Europe provides a lot of examples of controversial transitions, when, say, social and economic changes contradict the political transitions, while the changes taking place in some countries of Eastern and Central Europe do not conform with the transitions occurring in other states or regions of the same territory. Such negative phenomena, hampering the advance of the above states, call for the idea of harmonizing the transitions of controversial character, implying balancing of different changes. 
5. The innovative character of transitions, meaning that any transition accumulates some novelty. In the transition period, the innovative potential is intensely developed by providing the conditions for innovative activities. The novel character of transitions may be expressed in two ways : first, the conditions are created for adapting well - known models and solutions to some situation in a new way. In this case, they are considered to be innovative. Second, completely new, previously unknown models and solutions are made. In this case, these newly created patterns, having no analogues, are considered to be the innovations. The development of two types of novelties in the transition period emphasizes the importance of innovative activities for the countries of Eastern and Central Europe.

6. A positive character of transitions, implying that transitions yield positive results in most cases. In spite of the fact, that both positive and negative results are actually obtained in the conditions of transition, the predominance of positive results is a particular feature of transitions.

7. The idealistic and disappointing character of transitions, meaning that this period is characterized by the recurrence of "searching for the ideals - disappointment" cycles. The above cyclicity shows that at the beginning of transition the solution of urgent problems is usually associated with the achievement of certain ideals, while later the period of disappointment both in the very ideals and in the transition itself and its outcome, follows. For example, in the transition period in the countries of Eastern and Central Europe it was much expected from democratization and free market development. However, later the community was much disappointed with the results obtained. At the same time, the cycles of "idealization - disappointment" demonstrate the maturing of the society in the course of transition as well as its adaptability to actual environment.

8. Openness in the period of transitions, meaning that the tradition of openness, pub- licity and "transparency" becomes established, making it possible to develop democracy and free market economy. However, it is evident that the patterns of "the open society" being formed in the countries of Eastern and Central Europe do not completely conform with the long - standing traditions of openness existing in Western countries, especially in Europe. Nevertheless, the developing tendency of openness in the states of Eastern and Central Europe is generally considered as one of the major development trends in the transition period.

9. Harmonization of objective and subjective elements, implying that the character and orientation of transitions largely depend on a number of objective factors characterizing the objectively existing background of political, social and economic transformations as well as on subjective elements, reflecting personal interests, influence and lobbyist activities of various subjects (i.e. individuals, groups of people of various levels, clans, etc.). The above objective and subjective elements are characterized by certain degree of coordination and harmonization, therefore the harmony of these two factors should be considered as naturally determined phenomenon of the development of Eastern and Central European countries in the transition period. It should be noted that subjective factors play particularly important role: the interests of individual persons, groups of people of various levels, clans, etc. have a considerable effect on the political, socialand economic development of these countries.

10. Integrity and comparable character of transitions on a world scale, meaning that local transitions are integrated into the higher - level transition systems. This indicates that the above transitions are of an international character, promoting the process of globalization as well as internationalization of political, social and economic development and demonstrating that they are comparable and can be coordinated at an international level. It may be stated that the transitions taking place in the countries of Eastern and Central Europe 
are of paramount importance for their integration into the global and international political, social, economic, cultural and information structures, as well as being a factor contributing to the convergence of the mentality and lifestyles of the inhabitants of various countries.

11. The resonance factor, conditioning that transitions of various origin and nature could coincide in time. Therefore, the community has to endure a heavy burden of a number of transitions taking place simultaneously. The phenomenon of resonance indicates itself as the timing of political, social and economic changes causing a heavy burden on the community, which in turn may threaten its safety and stability.

The above - listed appropriate phenomena show general trends of transitions, which are universal and similar in all the states of Eastern and Central Europe. Along with these major trends some specific features may be observed in political, social and economic development of particular countries or groups of countries. The above trends are particularly characteristic of transitions taking place in the Baltic countries, including Lithuania. the Baltic region is specific in many ways, therefore the transitions taking place in it may be considered a specific case of conformity to natural laws.

The following features of transitions may be specially mentioned as mostly characteristic of the Baltic states, including Lithuania:

1. Higher resonance of transitions, implying that in the Baltic states some additional transitions associated with regaining independence and forming new modern states as well as the priority of integration into the Western system took place alongside the political, social and economic transitions characteristic of other countries of Eastern and Central Europe. This means that the transition resonance in the Baltic states was caused not only by the democratization of market relations common to Eastern and Central European countries, but also by the transitions associated with very rapid development of new national states and their integration into the Western system. Thus, transitions in the Baltic states were more diverse and extensive than those taking place in other countries of Eastern and Central Europe. Therefore, it may be stated that the higher transition resonance is a major characteristic feature of the Baltic region.

2. The conflicting character of national priorities and regional integration and internationalization trends, indicating that two opposite as well as mutually complementary tendencies are developed in the Baltic states. On the one hand, national businesses are seeking autonomy, even closeness and self-isolation, trying to get established on the national market by the exclusive right. On the other hand, the tendency of integration of the whole Baltic region and the cooperation of three Baltic states in political, social and economic areas is constantly growing. Though three Baltic states often compete with each other, more and more possibilities are revealed to pursue the unified policy of cultural, economic and information development.

Needless to say, that some more specific features of transitions taking place in the Baltic states may be identified. Undoubtedly, they may refer to one of these countries, for example, Lithuania. The transitions taking place only in one of the states may be referred to as individual features characterizing the development of a particular state.

Thus, the analysis of individual features of transitions taking place in Lithuania enables us to determine the effect of various geographical characteristics (e.g. configuration of neighboring countries, exceptional geographic position of Kaliningrad region and the like) on their development. Some other individual and specific factors also influence the transition processes in Lithuania. Among them are cultural and historical features (e.g. the influence of the catholic ethics, the development of Lithuanian state and the formation of Lithuanian nation, urbanization, the location of agricultural zones, etc.).

The specific features of transitions taking 
place in Lithuania complete a general system of naturally determined trends of development in the periods of transformations. The proper understanding of these phenomena helps to improve the political, cultural, social and economic life.

Further investigation and evaluation of naturally determined transitions and their major features would allow the states of Eastern and Central Europe to pursue more efficient policy of improving the conditions of development as well as promoting the integration of these countries into international political, social and economic structures.

\subsection{Liberalization in the countries of Central and Eastern Europe and its impact on further economic and social growth}

Modern economic and social development in Lithuania and other countries of the Baltic region and Central and Eastern Europe can be defined by several features. One of the most significant among them is inclination towards real liberalization, which can be observed in the steadily decreasing role of the states in economic regulation: the pace and trends of economic growth in Central and Eastern Europe gradually becomes determined by the initiatives, aptness and trends in the international market conjuncture of the local and foreign economic subjects rather than political decisions and activities of the Central and Eastern European states.

What is more, liberalization in the countries of Central and Eastern European countries is unique by reason of certain circumstances that had not had historic comparisons in the global practice.

There are some specific factors of liberalization in the countries of Central and Eastern Europe.

The first factor among them is specific image of the state importance, which has developed historically in the Central and Eastern Europe, portraying outcomes of the previous social and economic growth. The market relations in the countries of Central and Eastern Europe had been started to set up quite recently, besides, the circumstances and historical background for these relations are completely different from those of modern Western countries. In the West, market relations were undergoing their evolution under the gradual development of the industrial and post-industrial society, considering that in the Central and Eastern Europe novel market relations developed very rapidly and unevenly. In fact, market economy in the countries of the Central and Eastern Europe started developing just $12-15$ years ago, in the end of the last century, when the industrial and post-industrial society had been already created, and enormous economic and especially industrial potential had been accumulated; by the way, this potential reached rather high technological level for that époque and held orientations towards the influence of science-driven production and modern industries and technologies. This economic potential developed based on centralized plan system, consequently, in the countries of the Central and Eastern Europe the tradition of the absolute role of the state in the economic development was formed: historically nobody else but the state played the most important role in the economic growth. Importance and absolutism of the centralized plan system and the state role in economic development was embodied in the Central and Eastern Europe in the long-lasting and deep-rooted tradition, therefore, this tradition inevitably influenced economic growth of the country and afterwards, when the outdated plan system collapsed quite unexpectedly. This means that when market relations started developing $12-15$ years ago in the Central and Eastern Europe, this system inherited certain relics of the old system: it can be conceived as symbiosis of the economic system of the Central and Eastern Europe both in specific "Western" elements of market economy, and certain state absolutism tradition.

The aforementioned factor is very important for the reason that understanding of this 
enables us to assess the attitude towards the role of the state and its power to influence economic and social growth existing in the contemporary Central and Eastern Europe. It may seem surprising but even today, after more than decade after the implementation of the major attitudes towards the market relations development in these countries, in fact, all societal layers still strongly believe that the state remains to be a leading subject in economic advancement of the countries. This attitude is typical both to business community, who envision all their economic troubles and business failures, absolutely related to the state, and on the other hand, to experts of various spheres, who are free-lance employees, and relate their possibilities to advance economically and seek for well being also greatly depending on the state; by the way, conclusions of this kind were made a number of times based on different research results (Melnikas, 2002). This allows us to state in the mind of the contemporary societies of countries of the Central and Eastern Europe the role of the state is understood not only as critical, but also as the main factor for their economic and social headway.

The second factor, illustrating specificity of liberalization in the countries of Central and Eastern Europe is the fact that in these countries today there is a serious lack of resources and opportunities to more rapidly achieve at least the minimal level of the standards of development and well being, existing in modern Western countries. This means that Central and Eastern Europe will inevitably have to implement substantially different, if compared to Western countries, patterns ensuring economic growth and rise of well being: implementation of these patterns should guarantee focus of resources and development on critical to each country priorities that should be associated both to maximization of the pace of the growth and to the endeavors to ensure possibly more intensive increase of the value added. It is clear that under these circumstances an adequate action of the state as an active subject of economic development should emanate.
This action should address the purposeful establishment of the priorities for the economic development and implementation of the main priorities.

The third factor, picturing specificity of liberalization in the countries of Central and Eastern Europe is that among social layers in many of these countries mentality of "standards of double moral" still prevails. This mentality, which developed over a long period of the reign of the totalitarian system (in fact, by the end of the last century), expresses very popular in society incompatibility of the individual or group interests to the norms of social accountability. There is probability of the incompatibility of this kind in any, even very progressive society, including the Western ones, and this incompatibility is especially distinct in Central and Eastern Europe. This incompatibility sometimes turns into very threatening shapes: it can be seen in rising social and economic differentiation inside societies of the Central and Eastern Europe, evident lack of social accountability among political and economic elite, or dominating clan interests, when working on live problems of the society and its well being. In this regard it is important to note that manifestations of mentality of "standards of double moral" are quite important as a factor that can ambiguously influence the process of liberalization and sometimes bring negative subsequences to the society.

The circumstances, mentioned earlier, as well as some other factors, are very important, when assessing possibilities and perspectives for economic liberalization in the countries of Eastern and Central Europe. It is important to consider these circumstances in the context of integration into the European Union of these countries, especially because within the integrated economic domain of the European Union these countries and their economic subjects experience many new problems; among them as particularly important can be mentioned the problems of compatibility of economic subjects and rise of household well being and improvement of social security. By the way, understand- 
ing of these problems in the context of liberalization and ability to deal with them considering the conditions of the integration of the countries of Central and Eastern Europe into the European Union is a very important precondition to ensure successful implementation of integration processes and high pace of further economic growth.

\subsection{Character of the criteria, indicators and influencing factors, as a tool to assess transformations arising in societies}

Transformations arising in societies, their course and results depend on a few effects, determined by decisions defined by various policies.

In order to assess the transformations, occurring in societies, it is necessary to define various possibilities for the effects on these transformations: the idea of such definition is to set priorities for effects made by various policies.

First, it is worthwhile noting that the key criterion characterizing the course and results of the transformations occurring in societies is the growth of their economies. It is obvious that various indicators may reflect on the growth of the economies: among those the most critical ones are the gross domestic product and its increase, as well as the gross domestic product and its increase per capita.

The following criteria of the priorities for policies may strongly effect the growth of the economies:

- in the sphere of taxation and state budgeting - liberalization based on: a) reduction of taxes both for citizens and economic structures, along with liberation and simplification of the overall system of taxation and their administration; b) lowering of state liabilities related to the support of the social sphere at the expense of the state budget,

- in the sphere of investment policy - liberalization oriented towards the inducement of investment into all sectors of the economy, for that purpose setting tax incentives and exemption; simplifying state tax supervision and administration, and creation of equal investment opportunities for both foreign and local investors

- in the sphere of export promotion various incentives meant to increase export from those sectors of economies where export extension allows to dramatically increase the gross domestic product (especially, the added value) and also increase employment,

- in the sphere of scientific, educational and technological progress - various incentives mean to encourage creation and implementation of high technologies; extensively use public commodities, methods and technologies of the information society in all spheres of life, and improve the quality of studies, ensuring better opportunities for employment and compensation of highly qualified specialists,

- in the sphere of the law - various means to ensure both legal warranties and public security, necessary in the development of economies,

- $\quad$ in the sphere of social policies - various means to ensure social stability necessary in the economic development,

- in the sphere of foreign affairs - various policies to ensure possibilities for successful implementation of export and import to and from abroad,

- in the sphere of public administration - various means to ensure favorable conditions for public administration institutions activities towards successful economic development,

- in the sphere of public relations and mass media - various means for promotion of various attitudes concerning economic development as a basis for the well- being of all 
individuals and society; therefore, economic development deserves the priority consideration,

- in the sphere of regional policies means to ensure the use of the benefits of any region, in order to reach economic growth in general, and economic growth in particular regions,

- in other spheres - means to promote economic development based on various political, social, cultural, economic, technological and other factors.

Next, it is important to note that one more criterion characterizing the course and the outcomes of the changes occurring in the society is economic well-being of the citizens.

The economic well-being of the inhabitants can be seen in such indicators as overall income; overall standard of living, and the minimum standard of living per capita over a certain time span (a month or a year), as well as the inhabitant share with the living standard not lower than average.

The economic well-being of inhabitants can also be measured with other indicators, such as the structure of consuming and cumulative income, along with the growth of income and living standards.

Economic well-being of inhabitants may be assessed by other indicators.

In any case, the well-being of inhabitants can be greatly influenced by the following political priorities:

- in the sphere of taxation and state budgeting - there are two-fold measures: a) measures oriented towards a possibly lower portion of taxes for inhabitants, b) measures oriented towards a possibly broader scale of the state budget use in the increase of inhabitants' economic well-being (e.g. increase in salaries for public servants; social warranties, incentives, exemptions and compensations; grants and subsidies for particular sectors of economies; including culture, education, health care and social security),

- in the sphere of investment policy - there are two-fold measures: a) measures oriented towards investment extension for the sectors the development of which directly effects the increase of the inhabitants' economic well-being; b) measures dedicated to creation of favorable conditions for all inhabitants to promote investment in order to accumulated and increase their capital and subsequently increase their well-being,

- in the sphere of export promotion - there are means that allow to promote export and therefore increase employment; along with the income of employers and employees and at the same time benefit to the economic well-being of inhabitants,

- in the sphere of scientific, educational and technological progress - means meant to more steadily and intensely develop intellectual potential of both the whole society and each individual, in addition, to raise the intellectual level and professional competences of inhabitants, and at the same time improve the quality of human resources and manpower, and based on that to increase the well-being of inhabitants,

- in the sphere of the law - various means of the legal character that ensure legal warranties to all members of the society to licitly enhance the economic well-being,

- in the sphere of social policies - various means to create favorable social environment for the growth of economic well-being of all society, including the means oriented towards alleviation of the increasing social differentiation in the society can facilitate the growth of economic well-being of the society,

- in the sphere of foreign affairs - various policies to create preconditions for all members of society to legally use opportunities to raise economic well-being in co-operation with foreign partners, earning income abroad or otherwise improving their economic situation instigated by the development of foreign relations,

- in the sphere of public administration various means to create favorable administrative environment for enhancement of the wellbeing of all members of society,

- in the sphere of public relations and mass media - various means for creation of favor- 
able psychological and informational environment in the society, oriented towards the increase of well-being of all members of the society (it is important to note that in the sphere of public relations and mass media special attention should be paid to promotion of the values of enterprise, innovation and initiative, as well as priorities of ethics, morality, tolerance and social accountability),

- in the sphere of regional policies - means to ensure possibly smoother improvement of well-being of all members of the society and to achieve that regional discrepancies do not dramatically effect economic well-being of inhabitants (it is worth mentioning that regional policies should develop to the two goals: a) to possibly better use the benefits of all regions to ensure the growth of economic well-being of inhabitants; b) to possibly more efficiently $s t a-$ bilize the opportunities for the even economic well-being of inhabitants regardless the very different situation in the regions,

- in other spheres - means to promote the growth of economic well-being of inhabitants based on various political, social, cultural, economic, technological and other factors.

Third, it is important to mention that a very important criterion influencing the course and outcomes of the changes emerging in the society is the quality of life. In its turn, a term of the quality of life suggests as a complex and integrated indicator characterizing the anticipated average life expectancy of one inhabitant; the level of his or her physical and psychological health; the level of social warranties and security for them in the spheres of health care, education, culture, studies; the level of political and other freedom of the people, and the level of the quality of physical, biological and social environment of their life.

The quality of life as an indicator can quantitatively constitute a derivative of various variables measured by level points or ranges, in various scales characterizing various components of the quality of life.

The quality of life can be assessed either within a certain time span - a month or a year
- or by the rate of changes.

Assessing the quality of life it is necessary in all cases to consider certain political priorities:

- in the sphere of taxation and state budgeting - there are means to improve the quality of life based on state budgeting resources, giving priority to social warranties, as well as health care and social security, education, culture, science, studies and environment protection,

- in the sphere of investment policy there are means set for export opportunities promotion, providing better quality of life (one of these means is to apply a part of additional funds coming from export development in the improvement of the quality of life),

- in the sphere of scientific, educational and technological progress - means meant to consecutively pursue new achievements in scientific, academic or technology advancement, with the provision of implementation of these achievements in the improvement of the quality of life (the priority in these cases should be given to current issues of medicine, protection of nature and other problems of the improvement of the quality of life, therefore, enhancing science and studies and developing technological headway),

- in the sphere of the law - means to ensure social comfort and the high quality of life within the concept of legitimacy warranties,

- in the sphere of social policies - various means to ensure the high quality of life within the concept of social warranties and social security,

- $\quad$ in the sphere of foreign affairs - various policies to ensure secure and reliable co-operation with foreign partners; also develop multipart communication abroad, visit foreign countries and live there; besides, use possibilities of 
learning newest achievements of foreign cultures, science and technology and apply them in our lives (an important priority here is to ensure by the means of foreign politics the warranties for peace and international security that directly influence the quality of life),

- in the sphere of public administration - various means to create favorable administrative environment designed to improve the quality of life of all members of the society (a key priority here is to practically implement human and civic rights in all stages of relationship between individuals and the state and its institutions),

- in the sphere of public relations and mass media - means for promotion of favorable psychological and informational environment in the society, oriented towards the improvement of the quality of life (it is noteworthy mentioning that in the sphere of public relations and mass media special attention should be drawn to constructive and positive ideas and values spread in the society, oriented towards promotion of healthy lifestyle, moral behavior, culture, art, and sports, and consolidation of ecology-wise lifestyle, and humanistic, democratic and civic values),

- in the sphere of regional policies means to ensure a possibly higher level of the quality of life in all regions, showing special attention to preservation of nature, landscape and fostering of cultural heritage,

- in other spheres - means to promote improvement of the quality of life based on various political, social, cultural, economic, technological and other factors.

To conclude the statements given earlier, we may ascertain that for evaluation of the changes typical to the development of the society; the course of these changes and the out- comes and impacts of various policies affecting those changes it is possible and sometimes even advisable to apply other parameters and indicators than we have presented. It is critical to understand the fact that changes typical to the development of any society can be influenced by other policies or classification of the latter ones.

What is more is the fact that the viewpoint give above is universal, and allows defining the most common case when the most critical influences on course and outcomes of the changes occurring in the society are assessed.

The practical employment of the concept designed to evaluate the changes of the society influenced by various policies, explained earlier, can be very useful in the cases where analysis and forecast of the very important for the development of the society outcomes of the decision making preparation and implementation is needed. Such cases are of the great importance when alternative versions of decisions are compared, designed to prepare and implement the state economic policy.

The enlisted factors suggest that decisions about the issues discussed earlier with consideration of the utilization of methodologies given above comprise a very important prerequisite to ensure headway in all spheres of societal development.

\section{STRATEGIC DECISION-MAKING IN URBAN DEVELOPMENT AND THE CREATION AND ACCUMULATION OF PROPERTY: MULTICRITERIA EVALUATION}

\subsection{Various decisions and evaluation criteria used in the area of urban development and the creation and accumulation of property}

The main problem of strategic decisionmaking is associated with the identification of the subject and determination of the main interests and objectives of this subject. Various subjects may make different, often conflicting, 
decisions. This fact is of particular importance for the societies under transition when social structures and social groups are rapidly changing, as well as their possibilities, values and priorities.

In making strategic decisions on the problems of urban development and the creation and accumulation of property, the following most important subjects should be considered:

- a state as a subject representing the whole society through the prism of the interests of the leading political and economic forces (it should be clear that the interests of the state are of a dual nature: on the one hand, the state must represent the interests of the society as a whole, while, on the other hand, the state mainly perceives its interests as representing those of the leading political and economic forces), municipality as a subject representing the community and various political and economic forces acting in the name of the community,

- various social and economic groups and stratas having various interests and often acting as influential subjects,

- local and foreign business organizations (subjects) including international firms and enterprises,

- local and foreign social organizations with various social and cultural interests,

- $\quad$ a lot of individuals as physical subjects having a wide range of interests.

The above listed groups and individuals may have completely different views on the problems of urban development and the creation and accumulation of property. This means that in developing the strategies of urban development and the creation and accumulation of property the interests of the above parties and individuals should be harmonized.

Basing ourselves on the above consideration, we may formulate two types of problems to be solved in making the strategic decisions of urban development and the creation and accumulation of property:

- developing individual strategies of any subject,

- harmonizing strategies of various subjects aimed at developing and implementing a unified strategy.

To solve the above different problems, multiple criteria evaluation and optimization methods may be used:

- in developing individual strategies for subjects, these methods may be used so that any strategic decision would be oriented to a set of various criteria adequately describing the interests of an individual subject,

- in harmonizing strategies of various subjects and developing or grounding $a$ unified strategy, the above methods may be used to orient this general strategy to a balanced set of criteria adequately representing a group of subjects.

Multicriteria evaluation and optimization methods used for solving the problems of the above two types have been thoroughly studied and described in many theories (Low and Sloan, 2000; Deakin, 2002; Ginevičius and Podvezko, 2005; Then, 2005; Zavadskas and Kaklauskas, 1999; Zavadskas et al., 1999; Zavadskas et al., 2001a, Zavadskas et al., 2001b, Zavadskas et al., 2001c; Zavadskas et al., 2002; Zavadskas and Kaklauskas, 2003; Zavadskas et al., 2003a, Zavadskas et al., 2003b, Zavadskas et al., 2003c; Zavadskas and Antuchevičienè, 2004, Zavadskas et al., 2004a, Zavadskas et al., 2004b; Zavadskas and Kaklauskas, 2005).

The application of these methods enables reasonable strategic decisions to be made in various areas, implying that their use in the field of urban development and the creation and accumulation of property is appropriate and promising.

Using multiple criteria and optimization methods, it has been established that the key factor is the selection of a set of evaluation criteria. It is clear that this also applies to strategic decision - making in urban development 
and the creation and accumulation of property, particularly when transformations take place.

Taking into account the significance of the selection of criteria in considering the problems of urban development and the creation and accumulation of property in the period of transformation, these criteria will be discussed in more detail.

\subsection{The criteria describing urban development in the period of transformations}

The scientifically grounded selection of the criteria characterizing and evaluating urban development is the main aspect of the investigation of this problem from theoretical and practical perspectives. It should be clear that these criteria should reflect a general context of social development as well as taking into account the specific cultural and historical features of particular regions and countries. The latter is of special importance to the states of Central and Eastern Europe which are characterized by a great number of specific features greatly influencing urban development.

Urban development is closely connected with political, social and economic development of the community. This shows that this process should be considered in the context of societal transformations.

The transformations taking place in the states of Central and Eastern Europe in the last decade had a profound influence on urban development. Their impact on urban development in the states of Central and Eastern Europe was exceptionally great, therefore it may be considered as a specific feature of these countries. Other regions have not recently experienced such profound societal transformations, therefore, the factors of societal transformation influencing urban development in the countries of Central and Eastern Europe should be considered as extremely important.

The influence of societal transformations on urban development determines the need to consider some specific criteria characterizing ur- ban development in the states of Central and Eastern Europe. The major of them are as follows:

- criteria characterizing the construction of buildings, groups of buildings and neighbourhoods indicating the development of business,

- criteria characterizing the development of economic and cultural relations, particularly with foreign countries,

- criteria characterizing the increasing social and economic differentiation and the variety of lifestyles of urban population,

- criteria characterizing the increasing technological advances, the formation of knowledge society, new types of social behaviour and standards of well-being.

It is clear that some other criteria may be used to describe the influence of societal transformations on urban development, however, a set of the above criteria seem to reflect the main aspects of this problem.

The criteria characterizing the construction of buildings, groups of buildings and neighbourhoods indicating the development of business show that in the transition period every city becomes a center of business activity which is typical of the economy based on open and free markets. It may be stated that societal transformations reflecting the development of open and free market economy and the respective growth of business activity in every city may be described by the following criteria:

- the amount of various commercial buildings, their areas and spaces, the dynamics of these and other characteristics in the context of urban development characteristics,

- concentration of various business centres, office buildings and other structures reflecting business development on the territory of the city and other indicators of the formation of new zones of business activities and neighbourhoods (i.e. the amount of such 
zones and neighbourhoods, their territory and the available workplaces as well as their adaptability to providing services to certain amounts or flows of clients),

- the parameters reflecting urban architectural, economic and social significance of new buildings, groups of buildings and neighbourhoods indicating business development (i.e. various coefficients indicating architectural significance, attraction of flows of people, etc.).

The criteria characterizing the development of economic and cultural relations, particularly with foreign countries, show that under transition every city becomes the center of regional, interregional and international communication. It may be stated that the development of these relations in the period of societal transformations may be described by the following criteria:

- major parameters of the development of infrastructure for providing services and creating special centres for tourists and their dynamics (i.e. the capacities of hotels, restaurants and cafes, entertainment and recreational institutions, etc. and their growth),

- major characteristics of internationalization of the infrastructure and centres for tourism in the city and their dynamics (the criteria characterizing the activity of international networks for tourists in the city and economic, political and cultural activities at the international level indicating the international significance of cultural heritage),

- major parameters characterizing urban architectural significance of the development of buildings and areas for tourism centres, as well as cultural heritage.

The criteria characterizing the growing social and economic differentiation of urban population and their lifestyles indicate that the process of social, economic and cultural stratification of the society is taking place in the period of societal transformations. The differentiation primarily concerns city districts where people of different material well-being are concentrated. The differentiation of the inhabitants and their lifestyles may be described by the following criteria:

- provision of the inhabitants of various districts with the floorspace and quality standard of this living space including the average square area per capita, the variance of this indicator within the district and different structure of floorspace in various types of dwellinghouses (i.e. in blocks of flats and individual houses, etc.),

- the criteria characterizing the level of comfort from the perspectives of the development of infrastructure, the capacities of service sector, the environment, etc.,

- the criteria describing the variety of districts in terms of quality standards,

- the criteria describing the variety of the inhabitants of the city allowing for general description of the structure of urban population and its changes.

The criteria characterizing the accelerating technological advance, prevalence of knowledge society standards and implementation of new standards of social behaviour and well-being indicate that the development of any town or city is becoming more dependent on technological advances in all sectors of economy of the city and the activities of its inhabitants. They also demonstrate the prevalence of new standards of life reflecting the ideals of knowledge society. It may be stated that the influence of the accelerating technological advance, prevalence of knowledge society standards and implementation of new standards of social behaviour and well-being on urban development may be characterized by the following criteria:

- investments into economic restructuring of the city and the dynamics of 
investment as well as the relationship between these investments and other criteria of urban development and their profitability,

- capacities of various enterprises providing services in the city, including the calculation of services per capita or the unit of area,

- parameters characterizing the scope of innovations in urban development (i.e. the characteristics relating to innovations in infrastructure, urbanization innovations as well as changes in the structure of urban population and community).

It is clear that other criteria can be used to assess the influence of societal transformations on urban development alongside the abovementioned factors. However, a set of the selected criteria allows us to evaluate urban development from various perspectives as a societal transformation phenomenon, taking into account some specific features of the states of Central and Eastern Europe.

It may be stated that the improvement and expansion of the above set of criteria is a promising field of further research in the area of urban development. It should also be noted that a set of criteria should reflect the specific nature of particular cities and their development. In this sense, the development of Vilnius is a good example demonstrating the application of a differentiating approach to particular cities and their characteristics in the process of urban development.

Vilnius and its development have all features reflecting major aspects of urban development in societal transformation environment including those which are typical of the countries of Central and Eastern Europe. However, Vilnius and its development are characterized by a number of specific features the evaluation of which requires some additional criteria.

The main of these additional criteria are:

- the criteria characterizing Vilnius as the capital of a contemporary state in the expanding European Union,
- the criteria reflecting the specific historical, urban and landscape features of Vilnius as well as the prospect of the agglomeration of two cities - Vilnius and Kaunas.

The criteria characterizing Vilnius as the capital of a contemporary state in the expanding European Union reflect the significance of Vilnius to the EU development from political, cultural and economic perspectives. This significance may be described by the following criteria:

- the characteristics relating to the number of state and government institutions, various foreign representatives and international organizations and their staff, as well as the characteristics of the buildings occupied by these organizations, groups of buildings and their infrastructure reflecting their urban architectural significance,

- the influence of the capital status on economic development of the city and its social and cultural life (i.e. various characteristics reflecting this influence, for example, the scope of cultural events and economic and information-related activities, etc.).

The criteria characterizing the specific historical, urban and landscape features of Vilnius as well as the prospect of the agglomeration of two cities - Vilnius and Kaunas allow us to adequately assess the following factors:

- factors relating to the specific features of historic and cultural heritage and the landscape and lay-out of the city,

- factors relating to the prospect of forming an agglomeration of two cities - Vilnius and Kaunas.

Some more characteristics may be used to evaluate the development of Vilnius in the environment of societal transformations, however, it can be observed that the above additional criteria adequately reflect Vilnius development and its specific features. Therefore, researchers carrying out theoretical and empirical research in the above area can rely on this set of criteria.

In general, basing ourselves on the above 
considerations, we can state that the suggested set of criteria aimed to describe and evaluate urban development in the environment of societal transformations may be used as a typical set of criteria in investigating the problems of urban development.

\section{CONCLUSIONS}

Strategic management of urban development and the creation and accumulation of property under the conditions of societal transformations is an important and promising field of research and development.

The following factors determine the significance of the strategic management of urban development and the creation and accumulation of property under the conditions of societal transformations:

1. Urban development and the creation and accumulation of property are the most important indicators of current social and economic development, technological advance and the increase of standard of life. These processes reflect the results of societal transformations and the effects of the current changes on further development of the community;

2. Urban development and the creation and accumulation of property influence the general processes of political, social, and economic development. Therefore, urban development and the creation and accumulation of property may be considered to be the factors influencing societal transformation;

3 . The processes of the creation and accumulation of property are mainly concentrated in towns and cities. This allows us to define the concept of the city in several ways:

- the city as a system of the material and non-material property;

- the city as a social-economic system, the main feature of which is the creation and accumulation of property;

- the city as an environment of the creation and accumulation of property.

Urban development and the creation and accumulation of property as well as societal transformations are analyzed as a complex object of strategic management. Making and substantiating of strategic decisions largely depend on the subjects (parties) involved and their various interests and objectives. The main subjects making the most important decisions on urban development are the state, various political and economic forces, municipality, various social organizations and their representatives, business organizations, etc.

Strategic management of urban development and the creation and accumulation of property should be based on the application of multicriteria evaluation and optimization methods. These methods allow for harmonization of the interests of various parties and the development of balanced strategies.

In making decisions and implementing them in the conditions of social changes, the following criteria should be considered:

1. The criteria describing the influence of globalization and internationalization as well as the formation of knowledge-based society on urban development and the criteria relating to the emergence of new cultural patterns and lifestyles;

2 . The criteria describing business development and changes in business structure as well as their effects on urban development;

3 . The criteria describing international economic and cultural relations characteristic of urban development;

4. The criteria describing the structure of the community and its changes as well as social and economic differentiation and various lifestyles of urban population;

5. The criteria describing cultural heritage as well as historical, cultural and other specific features of the city.

Solving some particular strategic management problems, a set of criteria provided in the present paper may be expanded to meet the specific needs.

The problems associated with strategic management of urban development and the creation and accumulation of property is of particular importance for Central and Eastern 
Europe where societal transformations are taking place. Solving the above problems in this region, the priority should be given to the specific character of societal transformations. These features can be described in terms of basic principles of societal transformations, including a complex nature of transformations, their non-uniformity, 'leaps', the so-called 'resonance effect', etc.

The application of the provided data to solving actual problems of strategic management can help increase the effectiveness of urban development and the creation and accumulation of property, thereby activating social and economic development of the community.

\section{REFERENCES}

Altvater, E. and Mahnkopf, B. (1996) Limits of Globalisation: Politics, Economy and Ecology in the World Society, Muenster, Verlag Westfalisches Dampfboot, 33 p.

Boldrin, M. and Canova, F. (2001) Inequality and convergence in Europe-s regions: reconsidering European regional policies. Economic Policy, 16(32), p. 205-225.

Burinskienè, M. and Rudzkienè, V. (2004) Comparison of spatial - temporal regional development and sustainable development strategy in Lithuania. International Journal of Strategic Property Management, 8(3), p. 163-176.

Chortareas, G. E. and Pelagidis, T. (2004) Trade flows: a facet of regionalism or globalisation? Cambridge Journal of Economics, 28, p. 253271.

Cultures in Central and Eastern Europe, Ed. Bateman, M. (1997), Oxford, Boston, Butterworth - Heinemann, 238 p.

Cohendet, P. and Stojak, L. (2005) The digital divide in Europe. The economic and social issues related to "knowledge-based Europe. Futuribles: Analyse et Prospective, Issue 305, p. 5-28.

Currie, W. (2000) The Global Information Society, Chichester, John Wiley, 288 p.

Deakin, M. (2002) Computer based information systems, property management and the appraisal of land and buildings in the urban environment. Property Management, 6(1), p. 14-30.

Ein-Dor, P., Myers, M. and Raman, K. S. (2004) IT industry and the knowledge economy: A four country study. Journal of Global Information Management, 12(4), p. 23-49.

Farnsworth, K. (2005) Promoting business-centred welfare: International and European business perspectives on social policy. Journal of European Social Policy, 15(1), p. 65-80.

Ginevičius, R. and Podvezko, V. (2005) Objective and subjective approaches to determining the criterion weight in multicriteria models. Transport and Telecommunication, 6(1), p. 133-137.

Goeransson, B. and Soederberg, J. (2005) Long waves and information technologies - On the transition towards the information society. Technovation, 25(3), p. 203-211.

Grace, A. and Butler, T. (2005) Beyond knowledge management: Introducing learning management systems. Journal of Cases on Information Technology, 7(1), p. 53-70.

Hayo, B. and Seifert, W. (2003) Subjective economic well-being in Eastern Europe. Journal of Economic Psychology, 24(3), p. 329-348.

Hofbauer, H. (2003) Osterweiterung. Vom Drang nach Osten zur peripheren EU - Integration, Wien, Promedia, $240 \mathrm{~s}$.

Hui, E. C. M. and Tse, R. Y. C. (2002) Population mobility and land use policy in Hong Kong. Property Management, 6(2), p. 49-54.

Hunt, S. D. (2000) A General Theory of Competition: Resources, Competences, Productivity. Economic Growth, London, Sage Publications, 256 p.

Lavingne, M. (1995) The Economics of Transition: From Socialist Economy to Market Economy, London, Macmillan Press, 295 p.

Leung, B. Y. P. and Hui, E. C. M. (2005) Evaluation approch on public-private partnership (ppp) urban redevelopments. International Journal of Strategic Property Management, 9(1), p. 1-16.

Low, B. K. and Sloan, B. (2000) Current developments in internet - based electronic data interchange (EDI) and the implications for the construction industry. Property Management, $4(1)$, p. 23-30.

Melnikas, B. (1997a) The Integrations Problems of the Baltic States: Possibilities for the Formation of a Unified Technological, Economic and Social Space, East West Scientific Cooperation. Science and Technology Policy of the Baltic States and International Cooperation. NATO ASI Series, 4, Science and Technology Policy, Dordrecht, Boston: Kluwer Academic Publishers, Vol. 15. p. 33-51. 
Melnikas, B. (1997b) Real estate in the system of economic potential: development and management in conditions of transformations in Eastern Europe, In Zavadskas, E. K., Sloan, B. and Kaklauskas, A. (eds.), Proceedings of the international conference on property valuation and investment in Central and Eastern Europe during the transition to free market economy, Vilnius: Technika, p. 103-113.

Melnikas, B. (1998a) Development tendencies under transformation conditions, Intellectual Property Rights in Central and Eastern Europe: NATO Science Series, 4. Science and Technology Policy, Amsterdam, Berlin: IOS Press Ohmsha, Vol. 25, p. 96-107.

Melnikas, B. (1998b) Management and modernization of housing facilities: specific features of East and Central European countries, In Zavadskas, E. K., Sloan, B. and Kaklauskas, A. (eds.), Proceedings of the international conference on facilities management in Central and Eastern Europe and Commonwelth of Independent States, Vilnius: Technika, p. 355365.

Melnikas, B. (1998c) Management and modernization of housing facilities: specific features of Central and East European countries. Facilities, 16(11), p. 326-333.

Melnikas, B. (1999a) Real estate in system of economic potential: East European transformations. Real Estate Valuation and Investement, 3(1), p. 71-78.

Melnikas, B. (1999b) Probleme der Integration der baltischen Staaten in westliche Strukturen (Berichte des Bundesinstituts fuer ostwissenschaftliche und internationale Studien), N 40, Koeln, 1999, 42 s.

Melnikas, B. (2000) Real estate in the system of economic potential in Eastern Europe. Almanach des praktischen Managements in Mittel-and Osteurop, Stralsund: Nordic Academy of Informatization e.V., Band 2, s. 52-55.

Melnikas, B. (2002) Transformations, Vilnius: Vaga, 750 p. (in Lithuanian)

Melnikas, B. and Reichelt, B. (2004) Wirtschaft und Mentalitaet: Tendenzen der EU-Osterweiterung, Leipzig, Leifim-Verlag, 159 s.

Olsen, T. E. and Osmundsen, P. (2003) Spillovers and International Competition for Investments. Journal of International Economics, 59(1), p. 211-238.

Parker, B. (1998) Globalisation and Business Prac- tice: Managing Across Boundaries, London, Sage Publications, $672 \mathrm{p}$.

Perraton, J. (2001) The global economy - myths and realities. Cambridge Journal of Economics, 25, p. 669-684.

Politische und oekonomische Transformation in Osteuropa / Hrsg. G. Brunner, (2000), Baden Baden, Nomos, $252 \mathrm{~s}$.

Then, D. S. S. (2005) A proactive property management model that integrates real estate provision and facilities services management. International Journal of Strategic Property Management, 9(1), p. 33-42.

Weiss, E. (2003) Land regulation in urban agglomerations in the Federal Republic of Germany. International Journal of Strategic Property Management, 7(1), p. 10-21.

Weiss, E (2004) Replacing a combined tax on land and buildings with a simplified land value tax in the Federal Republic of Germany. International Journal of Strategic Property Management, 8(4), p. 241-245.

Zavadskas, E. K. and Kaklauskas, A. (1999) A new method of complex evaluation of projects based on multiple criteria analysis and the principle of proportionality, In Despotis, D. K. and Zopounidis, C. (eds.), Proceedings of $5^{\text {th }}$ International Conference on Integrating Technology and Human Decisions: Global Bridges into the $21^{\text {st }}$ Century, Athens, Greece, Vol. 2, p. 20512053.

Zavadskas, E. K., Simanauskas, L. and Kaklauskas, A. (1999) Decision support systems in construction, Vilnius: Technika, 236 p. (in Lithuanian)

Zavadskas, E. K., Kaklauskas, A. and Kvederytè N. (2001a) Multivariant design and multiple criteria analysis of a building life cycle. Informatica, 12(1), p. 169-188.

Zavadskas, E. K., Kaklauskas, A., Raslanas, S. and Malienè V. (2001b) The application of multicriteria methods for valuation of recreation property. Statyba (Civil Engineering), 7(4), p. 327-333.

Zavadskas, E. K. Kaklauskas, A., Lepkova, N. and Zalatorius, J. (2001c) Facilities management criteria analysis. Statyba (Civil Eugineering), 7(6), p. 481-489.

Zavadskas, E. K., Kaklauskas, A., Lepkova, N., Gikys, M. and Banaitis, A. (2002) Web-based simulation system for facilities management (FM), Advanced Computer Systems 
"ACS'2002"- “SCM'2002": Product System Design, Supply Chain Management and Logistics: $9^{\text {th }}$ International Conference. Part II: proceedings / Faculty of Computer Science \& Information Systems, Technical University of Szczecin, p. 514-522.

Zavadskas, E. K., Kaklauskas, A. and Trinkūnas, V. (2003a) Increase of efficience of construction materials e-commerce systems applying intelligent agents, Construction Innovation and Global Competitiveness. The Organization and Management of Construction / $10^{\text {th }}$ International Symposium on Construction Innovation and Global Competitiveness, Cincinnati, Ohio, September 9-13, 2002 - Crc. Press Inc., Boca Ration, p. 611-625.

Zavadskas, E. K., Kaklauskas, A., Vainiūnas, P., Kutut, V. and Turskis, Z. (2003b) Efficiency increase of internet based information in real estate by applying criteria decision support systems. Journal of Civil Eugineering and Management, 9, Suppl. 2, p. 83-90.

Zavadskas, E. K. and Kaklauskas, A. (2003) System approach in construction - scientific school of A.A. Gusakov (social-communicative sur- vey). Journal of Civil Eugineering and Management, 9(4), p. 253-259.

Zavadskas, E. K., Ustinovičius, L. and Peldschus, F. (2003c) Development of software for multiple criteria evaluation. Informatica, 14(2), p. 259272.

Zavadskas, E. K. and Antuchevičienè, J. (2004) Evaluation of buildings' redevelopment alternatives with an emphasis on the multipartite sustainability. International Journal of Strategic Property Management, 8(2), p. 45-55.

Zavadskas, E. K., Kaklauskas, A. and Raslanas, S. (2004a) Evaluation investments into housing renovation. International Journal of Strategic Property Management, 8(3), p. 177-190.

Zavadskas E. K., Kaklauskas, A., Vainiūnas, P. and Šaparauskas, J. (2004b) A model of sustainable urban development formation. International Journal of Strategic Property Management, 8(4), p. 219-229.

Zavadskas, E. K. and Kaklauskas, A. (2005) Decision Support System for Building Retrofit. Podium, Jg. 11, Sondernheft1, p. 18-22.

\section{SANTRAUKA}

\section{MIESTŲ PLĖTROS IR TURTO VALDYMAS VISUOMENĖS TRANSFORMACIJŲ SĄLYGOMIS: STRATEGINIŲ SPRENDIMŲ PRIĖMIMAS}

\section{Borisas Melnikas}

Kompleksiškai analizuojamos miestų plètros ir turto kūrimo bei kaupimo procesų strateginio valdymo problemos, pasireiškiančios visuomenès transformacijų sąlygomis. Parodomos galimybės pritaikyti daugiakriterinių sprendimų teoriją ir metodus plètojant ir tobulinant strategini valdymą šioje srityje.

Daugiausia dėmesio skiriama tokiems klausimams: miestų plètra visuomenės transformacijų sąlygomis kaip svarbus mokslinių tyrimų objektas turto strateginio valdymo srityje; miestai ir jų plètra kaip turto kūrimo ir kaupimo procesų aplinkos sektorius; visuomenès transformacijų procesai kaip bendrasis miestų pletros bei turto kūrimo ir kaupimo procesų kontekstas; pagrindinès transformacijų procesų tendencijos ir dėsningumai, pasireiškiantys Centrinès ir Rytų Europos šalyse, šių procesų vertinimo kriterijai ir indikatoriai; kriterijai, naudotini miestų plètros bei turto kūrimo ir kaupimo procesų strateginio valdymo reikmėms; daugiakriterinių sprendimų galimybės tobulinant miestų plètros bei turto kūrimo, kaupimo ir naudojimo strateginị valdymą. 